\title{
Impact of Organizations' Internal Green Supply Chain Management on Consumers' Purchasing Behavior for Personal Care Products
}

\author{
Byoung-Chun Ha \\ Department of Logistics, Services, Operations Management, \\ Sogang University, Seoul, Republic of Korea \\ Email: habc@sogang.ac.kr \\ So-Youn Lim \\ Department of Global Service Management, \\ Sogang University, Seoul, Republic of Korea \\ Email: limsy@sogang.ac.kr (Corresponding Author) \\ Changjoon Lee \\ Department of Logistics, Services, Operations Management, \\ Sogang University, Seoul, Republic of Korea \\ Email: cjlee0825@hanmail.net
}

\begin{abstract}
This study examines the impact of organizations' internal environmental management (IEM), which is one of the important factor of green supply chain management on consumer purchase behavior for sustainable personal care products. This study will provide information useful for managing internal corporate environments as a strategic way to create pro-environmental corporate images. Based on the theory of planned behavior, consumers' green purchasing behavior was measured using attitude, subjective norms, the perceived environmental friendliness of products and their subsequent purchasing behaviors for sustainable personal care products (PCP). The findings suggest that organizational IEM has a positive influence on purchasing behavior for PCP. Thus, corporate disclosure of IEM practices to consumers was found to exert a positive influence on their purchasing behavior. However, there was no significant relationship between the perceived environmental friendliness of products and consumer purchasing behavior. The present study discusses the implications for firms and recommends the integration of IEM and marketing strategy for environmental activities to create an eco-friendly personal care company.
\end{abstract}

Keywords: internal environmental management, attitude, subjective norm, perceived environmental friendliness, personal care products, consumer purchasing behavior

\section{INTRODUCTION}

Consumers concerned about environment and ethical consumption are more likely to prefer eco-conscious products (Han and Kim, 2010). Furthermore, they tend to avoid products containing hazardous materials and components (Liobikienè and Bernatoniene, 2017). This phenomenon of consumer consumption prompts strategic changes in the business context. Environmental decision making is increasingly promoted in relation to product production, marketing activities, and legislation establishment (Liobikiene et al., 2016). It is also considered a means of developing new business opportunities and competitive advantage for a company (Moser, 2015). Firms that internally promote environmental consciousness are more likely to provide consumers an enjoyable shopping experience and their image encourages them to buy the company's products (Chen and Chai, 2010).

Similarly, with ever-increasing health consciousness, consumers are more inclined to purchase organic food and sustainable personal care products (PCP) (Ritter et al., 2015), which includes body and skin care products, medications, and dietary supplements (U.S. Food and Drug Administration, 2018). As consumer preferences for environmentally friendly products have increased along with their growing interest in health and environmental concerns, the sales of sustainable PCP are now more than three times that of general products (Nielson, 2017). In the U.S., PCP constitutes the second largest organic market after food (Kim and Chung, 2011). Additionally, manufacturers of PCP are ready to make lavish investments in new green technology, materials, and production, among other areas (Cosmetics Design-Asia ${ }^{a}$, 2020). In particular, South Korea ranked ninth in the global cosmetics market with $\$ 11.6$ billion, and continued to grow with a $2.4 \%$ market share (Korea Cosmetics Association, 2019). In addition, the personal care market is headed for eco-friendly products such as zerowaste, eco-friendly packages, and plastic free or recycling due to consumer expectations (Cosmetics Design-Asia ${ }^{\mathrm{b}}$, 2020).

Despite the brisk growth of the sustainable PCP market, related research has several limitations. First, the related 
literature lacks an investigation into the causal relationship between internal environmental management (IEM) and consumer behavior (Boyce and Mano, 2018; Ta et al., 2015). Also, the internal environmental management of companies does not reflect the characteristics of products and consumers well (Tundys and Tomasz Wisniewski, 2020). Unreliable corporate promotion for and information disclosure about environment friendly products has resulted in distrust, fatigue, and consumer skepticism about such products (Albayrak et al., 2013). As a result, there is a gap in the consumer attitude toward and purchasing behavior for sustainable products (Moser, 2015; Olson, 2013). To close this gap, a consumer-oriented approach is necessary. Recent studies have reported that the integration of consumers viewpoints into IEM has helped firms establish new value and secure competitive advantage early (Bals and Tate, 2018; Fawcett and Waller, 2014). This study aims to examine the impact of organizational IEM on consumer purchase behavior by analyzing IEM practices based on theories collected from previous research.

Despite the potential growth of the green product market, most previous studies in this context focus on organic food (Kim and Chung, 2011; Yadav and Pathak, 2017). With respect to environmental sustainability, the existing studies addressed topics such as attitude (Chen, 2017), decision-making factors (Essoussi and Zahaf, 2008), label (Jonas and Roosen, 2005), and trust (Nuttavuthisit and Thøgersen, 2017). However, these variables were primarily associated with organic food and measured from a marketing perspective. Cho et al. (2015) explored the causal relationship between organizational IEM practices and consumer purchasing behavior, but their research interest was limited to organic food. PCP also has great growth potential due to burgeoning ecological problems (Kim and Chung, 2011). This study employs a segmented approach by focusing on the internal environment perspective, rather than the marketing perspective, and sustainable PCP among consumer goods.

To the best of our knowledge, no attempt has been made to investigate consumer behavior on sustainable PCP alone (Kim and Chung, 2011; Liobikienè and Bernatonienė, 2017). In other words, previous research addressed green products as a whole, without accounting for differences in their characteristics and properties (Liobikienè et al., 2016). Because personal care products come into direct contact with the skin or hair, corporate responsibility toward health and safety is crucial (Personal Care Products Council, 2020), and the unique characteristics of PCP may contribute to differences in the factors that affect consumer purchasing decisions when compared with other consumer products. Therefore, the characteristics of sustainable PCP must be independently investigated to distinguish this product category from general green products and organic food. Based on the limitations of previous studies, the present study examines the impact of organizational IEM practices on consumer purchasing behavior for sustainable PCP. First of all, the organizational IEM framework, proposed by Zhu and Sarkis (2004), was used as the main research method. Zhu and Sarkis (2004) divided organizational IEM practices into internal and external practices. As a component of internal management, IEM consists of corporate culture and employee engagement activities. IEM is defined as the first step toward achieving successful environmental performance in firms.

The present study assessed how organizational IEM affects consumers' green purchasing behavior. Ajzen (1991) developed the theory of planned behavior in which attitude, subjective norms, and perceived behavioral control are antecedents of intention to perform a behavior of interest. However, perceived behavioral control was excluded because it is not related to consumers' behavioral intentions toward sustainable products (Arvola et al., 2008) and because its limited concept scope lacks empirical evidence (Joshi and Rahman, 2015). It is, therefore, replaced by the perceived environmental friendliness of products (D'Souza et al., 2006; Lee et al., 2012; Rahbar and Wahid, 2011).

Overall, the present study pursues the following research objectives: First, we assess the effect of employees' environmental activities on consumers' decision-making process for purchases based on the analysis results. By measuring the IEM framework from a consumer perspective, we are able to suggest the need for consumer-oriented environmental management strategies. In addition, the present study explores IEM practices rather than marketing practices as a strategy for creating a pro-environmental image within firms. Finally, we suggest environmentally friendly sales strategies for sustainable PCP that differ from the strategies used for other green products. We also propose integrated environmental strategies that encompass both internal and external aspects by strengthening the internal efforts to produce sustainable products.

\section{LITERATURE REVIEW}

In the present study, variables were derived from the organizational IEM framework (Dou et al., 2018; Zue and Sarkis, 2004) and the theory of planned behavior (Ajzen, 1991; Kim and Chung, 2011; Liobikienè et al., 2016; Yadav and Pathak, 2017). Each variable was conceptually defined via the literature review, and the correlation between variables was assessed using a model.

\subsection{Internal Environmental Management}

IEM is a key factor in achieving and improving organization's green supply chain management (Zhu et al., 2008). Zhu and Sarkis (2004) defined IEM as top/middle management support and commitment, cross-functional cooperation to improve environmental performance, Total quality environmental management, environmental compliance, and audit programs. Among these, support and commitment from top management is described as a driver for shaping environmental practices (Zhu and Sarkis, 2004).

IEM is regarded as a key element driving environmental practices and performance in firms (Hoejmose et al., 2012). However, IEM has been measured mostly from the perspective of the enterprise and its employees, as well as the relationship between enterprises. Information on how sustainable products are manufactured and produced can be valuable to boosting environmental knowledge and trust among green consumers.

Furthermore, as consumers are more attentive to organizations' internal activities, their interest in IEM has increased (D'souza and Taghian, 2006). Recent studies reported that environmentally friendly processes, 
implemented and assessed within organizations for internal purposes, impact end-user consumers. For example, Hoejmose et al. (2012) claimed that growing demand for sustainable products increases consumer preference for green enterprises. It is also easy for consumers to collect information about suppliers through various channels. Meanwhile, businesses are becoming more transparent. All of these aspects imply that company decisions, even regarding internal activities, must reflect consumer needs (Ta et al., 2015). More importantly, producer-consumer collaboration in the production process has begun (Pattnaik and Pattnaik, 2019). Boyce and Mano (2018) stated that the inclusion of end-users in corporate decision making makes it possible for consumers to select the suppliers they prefer. With increasing information and consumer knowledge, visual only forms of promotion, such as advertising, are not enough to appeal to consumers. This applies to sustainable products. Kong et al. (2014) asserted that advertisements of green enterprises are no longer trusted by consumers. Nuttavuthisit and Thøgersen (2017) described a lack of consumer trust as the biggest barrier for developing an organic food market. This signifies that building consumer trust can be the most important strategy for manufacturers of sustainable PCP.

We conducted a literature review to identify criteria for measuring organizational IEM. The increasing role and collaboration of end consumers in an organization's internal activities enables firms to develop new strategies and to create new value (Mukhtar and Azhar, 2020). In particular, a consumer's likelihood of choosing sustainable PCP was high among consumers who advocate for human safety and environmental protection (Kim and Seock, 2009). In light of this, sharing information on organizational IEM with consumers will eventually encourage consumer trust toward green enterprises even though such information has not been available to the public. Disclosure of such information may become a determinant of purchase intention. Therefore, a conceptual framework of organizational IEM practices, expanded with a consumer viewpoint, needs to be developed. By measuring IEM from a consumer perspective, we will examine the causal relationship between organizational IEM and consumer purchase behavior toward sustainable PCP.

\subsection{Green Purchasing Behavior}

Based on Ajzen's (1991) theory of planned behavior, consumers' green purchasing behavior was predicted based on their attitudes, subjective norms, and the perceived behavioral control. This theory is the most commonly used in the research related to consumer purchasing behavior in eco-friendly products (Paul et al., 2016). In this paper, perceived behavioral control factor was eliminated due to limited research in the area (Joshi and Rahman, 2015). Instead, perceived environmental friendliness of products was added based on prior research. In addition, intention, which is one of the factor of the theory of planned behavior, has low correlation with behavior (De Cannière et al., 2009) and prior study found the gap between intentions and behavior (Carrington et al., 2014). For those reason, the intention was also eliminated in this study.

\subsubsection{Attitude}

Attitude refers to the degree to which a person has a favorable or unfavorable evaluation for a company or product (Ajzen, 1991). The relationship between attitude and behavior is described as a step to making a psychological decision based on beliefs. Ajzen and Sheikh (2013) asserted that intention to perform or not perform behavior can be predicted from a person's past behavior. De Leeuw et al. (2015) mentioned that a consumer's favorable attitude toward green products leads to positive behavior.

As consumers become more attentive to internal corporate activities, IEM has been identified as a factor that can positively affect consumer attitude. Han and Kim (2010) argued that the environmental efforts and processes implemented within an organization should be also advertised. In their study, such an attempt led to positive consumer attitudes and increased purchase intentions. Pudaruth et al. (2015) mentioned that consumers who are highly conscious about health and safety show positive attitudes toward sustainable consumption for hair, body, and skin care products. However, they added that a positive attitude is difficult to transform into behavior of interest due to a lack of trust and information and that the disclosure of information on green products, including manufacturing processes, would reduce consumer distrust toward products. Thus, organizational IEM has the potential to elicit more favorable consumer attitudes and to influence purchasing behavior.

However, some studies showed no effect of consumer attitude on purchasing behavior. Moser (2015) and Olson (2013) reported that positive consumer attitudes did not translate to purchasing behavior. In particular, eco-friendly advertising does not elicit a favorable consumer attitude (Chen and Chai, 2010; Kong et al., 2014). Given that sustainable products exert different effects on consumer attitude, depending on their features (Liobikienè et al., 2016), the present study's results may not be consistent, particularly with the findings of previous research. Overall, most previous studies confirmed that favorable consumer attitudes lead to purchasing behavior (Ghazali et al., 2017; Hsu et al., 2017; Kim and Chung, 2011; Liobikienè et al., 2016). However, there are few studies that verified the causal relationship between organizational IEM and consumer attitude. Considering the need for research in this area, we examine the impact of organizational IEM on consumer attitude.

\subsubsection{Subjective norm}

Subjective norm is a determinant of whether or not one performs a behavior of interest based on perceived social pressure. It refers to a step in the process of making a psychological decision whether or not to perform a behavior based on the influence of the important people around an individual (Ajzen, 1991). Paul et al. (2016) and Han and Kim (2010) described subjective norm as the influence of the people who are close or important to an individual, such as business partners, colleagues, and friends. Subjective norm has an important influence on consumer motivations to purchase green products, and it becomes stronger when consumers receive the attention of others (Suki, 2016). 
Liobikienè and Bernatonienè (2017) stated that the positive subjective norms of consumers can promote green purchasing behavior. Along with attitude, subjective norm is the most influential predictor of the health-related social behaviors of individuals. It is also a known variable of consumer acceptance, enthusiasm, and interest toward the environment (Hsu et al., 2017).

However, subjective norm was found to have no effect on green products (Connell, 2010; Paul et al., 2016). These studies claimed that subjective norm is neither controllable by individuals nor easily changeable in its nature, thereby exerting no significant effect on green purchase behavior. However, buyer motivations vary according to product attributes (Liobikienè and Bernatonienè, 2017), thus consumers may have different motivations for purchasing green products, in general, and sustainable PCP, in particular. To date, a positive correlation was observed between subjective norms and purchasing behaviors of sustainable PCP (Hsu et al., 2017; Kim and Chung, 2011; Liobikienè and Bernatonienè, 2017).

Furthermore, advertising, media, charitable activities, and CSR have been the primary factors reported to contribute to positive subjective norms because most previous studies addressed marketing strategies (Han and Kim, 2010). Although IEM has been found to have a positive effect on both employees and consumers (Hoejmose et al., 2012), almost no studies have investigated the causal relationship between organizational IEM and subjective norms. Therefore, this study examines the relationship between subjective norms and IEM and how it is correlated with consumer purchase behavior.

\subsubsection{Perceived environmental friendliness of products}

Perceived environmental friendliness of products is defined as the ability of products to cause minimal harm to the environment during the products' life cycles (Albino et $a l .$, 2009). Greater awareness of green products results in more positive outcomes, such as achieving competitive advantage, creating ethical corporate image, and improving market share, for firms (D'Souza et al., 2006). Consumer awareness of green products rapidly increases a firm's reputation for company-wide environmental efforts. Lee et al. (2012) ascertained that the effect of positive consumer experience with products they perceive to be environmentally friendly on consumer purchase behavior is greater than the advertising effect. It is said that simply creating strong consumer awareness of green products can be a differentiated strategy (Rahbar and Wahid, 2011). The perceived environmental friendliness of products helps create a positive image at the societal level, and its positive effect increases when in regard to sustainable PCP (Kim and Seock, 2009). Consumers believe that their purchases of sustainable PCP allow them to contribute to environmental protection in addition to meeting their health and beauty care needs (Kim and Chung, 2011; Liobikienè and Bernatonienè, 2017).

However, consumers are known to identify sustainable products through packaging and labels (Albayrak et al., 2013), ingredients (D'Souza et al., 2006), and advertisements (Tseng and Hung, 2013). TV and newspaper advertising help increase consumers' environmental knowledge; however, their impact on consumer purchasing behavior is meager (Rahbar and Wahid, 2011). Kong et al. (2014) reported that perceived green enterprises, labels, and the environmental impact of products are positively related with consumer awareness of sustainable products, whereas eco-friendly advertising and packaging are negatively related.

Although advertising is designed to make consumers aware of sustainable products, such an advertising strategy does not seem to be as effective as intended. In addition, the factors that consumers perceive as demonstrating the environmental friendliness of products may vary with product attributes. To overcome this, a thorough consumerbased measurement approach is necessary. Therefore, the present study examines how IEM practices influence consumer perception of the environmental friendliness of products. In other words, we use a literature review to examine how organizational IEM, measured by consumer perception of environmental friendliness, is correlated with consumer purchasing behavior.

\subsubsection{Behavior}

Human behavior can be predicted by attitudes, subjective norms, and perceived behavioral control (Ajzen, 1991). This theory has been widely adopted in studies related to green products and consumer behavior. According to Paul et al. (2016), most previous studies related to consumers' purchasing behavior toward green products used Ajzen's theory (1991). Yadav and Pathak (2017) cited the theory of planned behavior as the most useful theory for explaining human behavior from a psychological perspective. Based on this theory, many previous studies have identified attitudes and social norms as predictor variables associated with consumer purchasing behavior toward sustainable products; therefore, the theory's effectiveness has been proven even though it is not suitable for predicting complex social behavior.

Meanwhile, consumers' green purchase behavior can be interpreted in different ways. Todd (2004) described such behavior as a form of environmental concern and added that interactions with green consumers can bring new value to business. In developed countries, green consumption flows are characterized as being environmentally friendly, sustainable, and ethical (Yadav and Pathak, 2017). This signifies the growth of sustainable consumption following consumer advocacy for environmental perception and behavior. Amid growing concerns about the environment and health, an increasing number of people look for organic food and sustainable PCP (Marcoux, 2000; Ritter et al., 2015). Unlike general consumer goods, PCP is largely used for hair, the body, and skin. Hence, consumers tend to check ingredients and materials more carefully when purchasing sustainable PCP than they do for other general green products (Nijkamp et al., 2015).

With a growing consumer preference for sustainable products and associated markets, organizational IEM practices are changing accordingly. IEM was first implemented using management responsibilities and was measured by outcomes (Dou et al., 2018). A recent study claims that firms need new strategies to create new value by incorporating consumer perspective and collaboration into their internal activities (Ta et al., 2015). According to Boyce and Mano (2018), socially responsible decision making 
becomes more important to businesses as their environmental activities begin to draw attention, and consumer integration into their internal activities is essential to appealing to shoppers. For instance, the measurement and evaluation of organizational IEM must include input from end-user consumers. New strategies are necessary to create environmental value with a consumer-oriented perspective. Therefore, the present study aims to analyze whether organizational IEM contributes to building a solid environmental image and exerting a positive impact on consumer purchasing behavior.

\section{DERIVATION OF HYPOTHESIS AND RESEARCH MODEL}

As described above, the literature review led us to identify five main dimensions: IEM, attitude, subjective norms, the perceived environmental friendliness of products, and consumer purchasing behavior. The following hypothesis statements are formulated as a result.

Organizational IEM is a company-wide environmental action as all parties, from top management to suppliers, are involved to produce sustainable products. According to Hoejmose et al. (2012), the disclosure of information about the production of green products not only helps consumers increase their environmental knowledge, it also reduces their distrust. Thus, organizations' internal environmental activities are expected to have a positive effect on consumer attitude, as described in hypothesis 1.

As discussed above, previous research related to green purchasing behavior has clearly established the role of subjective norms, along with attitude, as a significant predictor of individual behavior. In addition, the image of sustainable products, created as a result of marketing activities, was found to influence the subjective norms of consumers: consumer trust toward sustainable products declines, and consumer interest in corporate internal activities increases. Hypothesis 2 was formulated with regard to consumers' positive image of marketing and internal practices as this is estimated to positively influence the subjective norms of consumers. In addition to attitude and subjective norms, the perceived environmental friendliness of products also impacts purchasing behavior. Firms can differentiate their strategies for increasing consumer awareness of sustainable PCP by disclosing their manufacturing processes or environmental management activities. Therefore, a positive relationship between IEM and the perceived environmental friendliness of products is expected, as described in hypothesis 3 .
H1. Organizational IEM has a positive impact on consumers' attitude.

H2. Organizational IEM has a positive impact on consumers' subjective norms.

H3. Organizational IEM has a positive impact on consumers' perceived environmental friendliness of products.

Attitude and subjective norms are accepted as leading behavioral variables. We differentiated the present study from previous literature by adopting internal environmental activities as an independent variable. Favorable consumer attitudes significantly influence their purchasing behaviors (De Leeuw et al., 2015) or repurchase intentions (Han and Kim, 2010). Taken together, green product image, derived from organizational IEM practices, is expected to elicit positive consumer attitudes and positively affect purchasing behaviors toward sustainable PCP, as described in hypothesis 4 . Subjective norms also play an important role in consumer purchasing behavior for sustainable PCP (Paul et al., 2016; Suki, 2016); therefore, hypothesis 5 was formulated based on the literature review. Finally, sustainable PCP, as perceived based on organizations' internal environmental activities, is also expected to positively impact consumer purchasing behavior. The impact of perceived environmental friendliness of products on consumer purchasing behavior has been clearly documented (Jonas and Roosen, 2005; Lee et al., 2012). That is, this variable, like attitude and subjective norms, has a positive relationship with purchasing behavior. Given that determinants of consumer attitude vary with green product attributes (Liobikienè and Bernatonienè, 2017), we examine whether the perceived environmental friendliness of products influences purchasing behavior differently in two categories-sustainable PCP and other sustainable consumer goods under-hypothesis 6 .

H4. Consumer attitude has a positive impact on purchasing behavior for sustainable PCP.

H5. Consumers'subjective norms have a positive impact on their purchasing behavior for sustainable PCP.

H6. Consumers' perceived environmental friendliness of products has a positive impact on their purchasing behavior for sustainable PCP.

As shown in Figure 1, we created a conceptual model to empirically test all hypothesis. 


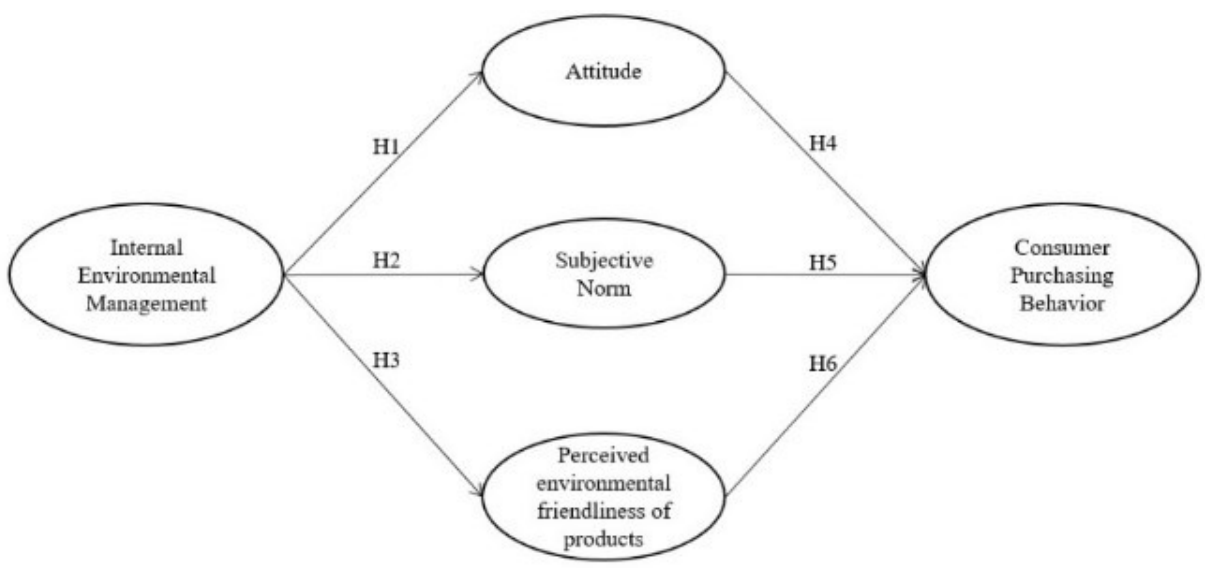

Figure 1 Research Model

\section{RESEARCH METHODS}

The present study empirically examines the impact of organizational IEM on consumer purchasing behavior for sustainable PCP using following analytical methods. First, Cronbach's $\alpha$ was calculated to measure internal consistency. Average variance extracted (AVE) estimates and construct reliability were calculated to evaluate convergent validity. To verify discriminant validity, latent variables were measured by comparing the coefficient of determination between latent variables with AVE value. Finally, structural equation modeling (SEM) and path analysis were performed for hypothesis testing (Hair et al., 2010). Reliability was tested by performing factor analysis with SPSS 18.0, and the fit of path analysis was tested using AMOS 18.0.

\subsection{Data Collection and Characteristics of Sample}

To collect data for empirical analysis, a questionnaire was developed with constructs adopted from previous studies and a pre-test was administered to 10 respondents with former experience. Once the questionnaire items were amended and validated, a full-scale survey was conducted online by a research company between October and November 2019. A total of 575 questionnaire copies were administered to consumers, and 257 were collected (a response rate of $44.69 \%$ ). The variables and concepts were measured on each construct in line with previous studies and are summarized in Table $\mathbf{1}$ and $\mathbf{2}$. Each questionnaire item was measured on a 7-point Likert scale.

Table 1. Latent and Manifest Variables

\begin{tabular}{|c|c|}
\hline Items & Internal Environmental Management \\
\hline IEM 1 & $\begin{array}{l}\text { The degree to which you think that employees are making significant efforts } \\
\text { in eco-friendly management }\end{array}$ \\
\hline IEM 2 & $\begin{array}{l}\text { The degree to which you think that the company is exercising quality control } \\
\text { in eco-friendly internal facilities }\end{array}$ \\
\hline IEM 3 & $\begin{array}{l}\text { The degree to which you think that there will be a supervisory program to } \\
\text { comply with environmental protection legislation }\end{array}$ \\
\hline \multirow[t]{2}{*}{ References } & $\begin{array}{l}\text { Hoejmose et al., (2012); Zhu et al., (2008); } \\
\text { Zhu and Sarkis (2004) }\end{array}$ \\
\hline & Attitude \\
\hline ATT 1 & $\begin{array}{l}\text { Purchase of PCP and the level of favorability to take action for environmental } \\
\text { protection }\end{array}$ \\
\hline ATT 2 & $\begin{array}{l}\text { The level of favorability when motivated to purchase PCP upon } \\
\text { hearing news related to environmental pollution }\end{array}$ \\
\hline ATT 3 & The level of favorability toward investment value in PCP \\
\hline \multirow[t]{2}{*}{ References } & Hsu et al., (2017); Paul et al., (2016); Yadav and Pathak (2017) \\
\hline & Subjective Norm \\
\hline $\mathrm{SN} 1$ & Have considered the purchase of PCP as a result of the influence of others \\
\hline SN 2 & Have considered the purchase of PCP after exposure to media information \\
\hline SN 3 & $\begin{array}{l}\text { Have considered the purchase of PCP based on information on } \\
\text { environmental organizations and groups }\end{array}$ \\
\hline References & $\begin{array}{l}\text { Kim and Chung (2011); Liobikienè and Bernatonienè (2017); } \\
\text { Paul et al., (2016) }\end{array}$ \\
\hline
\end{tabular}


Table 2. Latent and Manifest Variables (Con't)

\begin{tabular}{cl}
\hline & \multicolumn{1}{c}{ Perceived Environmental Friendliness } \\
\hline PEF 1 & Products with a green label/certification \\
\cline { 2 - 2 } PEF 3 & Products of enterprises embracing green management practices \\
\cline { 2 - 2 } References & Products subject to information and environment protection laws \\
\cline { 2 - 2 } & $\begin{array}{l}\text { D'Souza } \text { et al., (2006); Ghazali } \text { et al., (2017); } \\
\text { Rahbar and Wahid (2011) }\end{array}$ \\
\hline \multirow{2}{*}{ CPB 1 } & $\begin{array}{l}\text { The degree to which you purchase PCP in consideration of } \\
\text { environmental pollution }\end{array}$ \\
\cline { 2 - 2 } CPB 2 & $\begin{array}{l}\text { The degree to which you would select an PCP if you had to choose between } \\
\text { an eco-friendly product and a generic product }\end{array}$ \\
\cline { 2 - 2 } CPB 3 & $\begin{array}{l}\text { The degree to which you prioritize purchasing products with eco-friendly } \\
\text { certification indicators or labels }\end{array}$ \\
\cline { 2 - 2 } References & $\begin{array}{l}\text { Ajzen and Sheikh (2013); Liobikienè } \text { et al., (2016); } \\
\text { Rahbar and Wahid (2011) }\end{array}$ \\
\hline
\end{tabular}

The characteristics of respondents who completed the questionnaire are summarized in Table 3. Of 257 respondents, $51.4 \%$ were female and $48.6 \%$ were male, showing almost even gender distribution. By age, the proportion of 10-29 years respondents was high. Overall, the majority of respondents were young, graduated from college and employed with regular income; therefore, the study population appropriately represents the social-economic status of consumers.

Table 3. Sample Characteristics

\begin{tabular}{cccc} 
& & & $(\mathrm{N}=257)$ \\
\hline \multirow{2}{*}{ Variable } & Categories & Frequency $(\mathrm{N})$ & Percentage $(\%)$ \\
\hline \multirow{2}{*}{ Gender } & Male & 125 & 48.6 \\
& Female & 132 & 51.4 \\
\cline { 2 - 4 } Age & 10-29 years & 125 & 48.7 \\
& 30-59 years & 103 & 40.0 \\
\multirow{4}{*}{ Education } & More than 60 years & 29 & 11.3 \\
\cline { 2 - 4 } & High school graduation & 56 & 21.8 \\
& College graduation & 186 & 72.4 \\
Monthly income & 15 & 5.80 \\
\cline { 2 - 4 } & Graduation school graduation & 76 & 29.5 \\
\cline { 2 - 4 } Monthly & Less than 1million won & 102 & 39.7 \\
shopping & 1million $\sim$ 2million won & 56 & 21.8 \\
expenditure & 3million $\sim$ 4million won & 23 & 9.00 \\
\cline { 2 - 4 } & More than 5million won & 191 & 74.3 \\
& Less than 1million won & 56 & 21.7 \\
& 1million $\sim$ 2million won & 9 & 3.50 \\
& 3million $\sim$ 4million won & 1 & 0.40 \\
\hline & More than 5million won & 257 & 100.0 \\
\hline
\end{tabular}

\subsection{Measurements of Variables}

Using a 7-point Likert scale, this study analyzed 15 items measured on five latent constructs (IEM, attitude, subjective norms, the perceived environmental friendliness of products, and purchasing behavior for sustainable PCP), which were identified through the literature review.

IEM is a key to the success of corporate environmental performance (Zhu et al., 2008). In particular, the active role of top management in the introduction and implementation of pro-environmental processes is crucial to determining an organization's attitude toward and commitment to environmental practices. Business with firms furnished with an environmental management system and monitoring of internal environments have been used as major components to measure organizational IEM (Zhu et al., 2008). Ajzen (1991) divided attitude into instrumental and experiential attitude and measured them using a 7-point Likert scale, anchored by good/bad and pleasant/unpleasant. Because consumers have become more attentive to companies' internal activities (D'souza et al., 2006), consumer attitudes toward internal activities were measured.

Subjective norms, which were divided into injunctive and descriptive norms, were measured on a 7-point Likert scale, ranging from one extreme to the other (e.g., 
agree/disagree and likely/unlikely) (Ajzen, 1991). Based on the literature view, we also assessed whether social pressure that supports sustainable PCP is significantly related to consumer purchasing behavior for sustainable PCP. The perceived environmental friendliness of products can influence consumer behavior and serves as an important factor in promoting the environmental awareness and competitive advantage of firms (Pujari, 2003).

It was found that consumers are able to distinguish the products produced by high-performing green manufacturers, in terms of labeling practices, pro-environmental image, and environmental compliance, from other products (Kim and Seock, 2009; Kong et al., 2014). Consumer awareness of sustainable products was measured based on previous studies. Finally, previous research also showed that consumers prioritize the perceived health and safety of products when purchasing sustainable PCP. Consumers' perception level was used to distinguish sustainable PCP from other green products and their preferences for sustainable PCP were also measured.

Table 4. Results of Reliability and Convergent Validity Analysis

\begin{tabular}{|c|c|c|c|c|c|c|c|}
\hline Items & Estimate & S.E. & $\mathrm{T}$ & $\mathrm{P}$ & AVE & CR & Cronbach's \\
\hline IEM1 & 1.000 & - & - & - & & & \\
\hline IEM2 & 1.169 & 0.099 & 11.805 & $* * *$ & 0.609 & 0.821 & 0.815 \\
\hline IEM3 & 0.855 & 0.083 & 10.301 & $* * *$ & & & \\
\hline ATT1 & 1.000 & - & - & - & & & \\
\hline ATT2 & 1.236 & 0.104 & 11.870 & $* * *$ & 0.596 & 0.815 & 0.802 \\
\hline ATT3 & 0.973 & 0.092 & 10.618 & $* * *$ & & & \\
\hline SN1 & 1.000 & - & - & - & & & \\
\hline SN2 & 1.043 & 0.103 & 10.118 & $* * *$ & 0.587 & 0.809 & 0.770 \\
\hline SN3 & 1.220 & 0.119 & 10.259 & $* * *$ & & & \\
\hline PEF1 & 1.000 & - & - & - & & & \\
\hline PEF2 & 1.118 & 0.118 & 9.443 & $* * *$ & 0.542 & 0.780 & 0.810 \\
\hline PEF3 & 1.259 & 0.134 & 9.365 & $* * *$ & & & \\
\hline CPB1 & 1.000 & - & - & - & & & \\
\hline CPB2 & 0.801 & 0.073 & 10.962 & $* * *$ & 0.587 & 0.809 & 0.809 \\
\hline CPB3 & 0.962 & 0.086 & 11.147 & $* * *$ & & & \\
\hline
\end{tabular}

*IEM: Internal environmental management, ATT: Attitude, SN: Subjective norm, PEF: Perceived environmental friendliness, CPB: Consumer purchasing behaviour

\subsection{Reliability and Validity Tests}

Arbuckle (2006) proposed the use of structural equation analysis in two steps as a hypothesis testing method. In the first step, we examined the internal consistency and reliability of the measured variables by calculating Cronbach's $\alpha$ and then assessed the validity of the scale items using confirmatory factor analysis. Specifically, convergent validity was tested by calculating AVE values and construct reliability (CR), and discriminant validity was tested by comparing AVE values and the coefficient of determination (R2) between latent constructs. In the second step, we performed SEM and path analysis to test hypothesis.

The internal consistency reliability of the measured variables, measured with Cronbach's $\alpha$, showed greater than 0.7 for all items, indicating an acceptable level of reliability (Hair et al., 2010). The values of CR and AVE, calculated to test convergent validity, are presented in Table 4. All AVE values were greater than 0.5 , and all $C R$ values were greater than 0.7 , indicating the establishment of convergent validity in the variables measured on each latent construct. To test goodness of fit of the SEM, including confirmatory factor analysis, we evaluated the values of the comparative fit index (CFI), goodness-of-fit-index (GFI), adjusted goodness-offit-index (AFGI), Tucker-Lewis index (TLI), normed fit index (NFI), root mean square error of approximation (RMSEA), and root mean square residual (RMR). In general, model fit is acceptable with the threshold values of RMR $(<$ $0.05)$, RMREA $(<0.08)$, and other indices $(>0.90)$ (Hair et al., 2010). Fit indices used to assess confirmatory factor analysis revealed $x^{2}=111.751(\mathrm{DF}=80), \mathrm{CMIN} / \mathrm{DF}=$ $1.397, \mathrm{GFI}=0.945, \mathrm{AGFI}=0.918, \mathrm{CFI}=0.979, \mathrm{TLI}=$ $0.972, \mathrm{NFI}=0.931, \mathrm{RMSEA}=0.061, \mathrm{RMR}=0.039$, all of which met the values for acceptable fit.

Table 5. Results of Discriminant Validity Analysis

\begin{tabular}{cccccc}
\hline & IEM & ATT & SN & PEF & CPB \\
\hline IEM & 0.780 & - & - & - & - \\
ATT & 0.437 & 0.772 & - & - & - \\
SN & 0.387 & 0.575 & 0.766 & - & - \\
PEF & 0.267 & 0.440 & 0.254 & 0.736 & - \\
CPB & 0.406 & 0.432 & 0.579 & 0.133 & 0.766 \\
\hline
\end{tabular}


Discriminant validity was also tested to ensure mutual independence between the latent variables that constitute the model. Table 5 shows the results of comparing the square of

\section{EMPIRICAL RESULTS}

Table 6 presents the path analysis results of the model developed for hypothesis testing based on verified reliability and validity. Maximum likelihood estimation (MLE) was used at each step of the path analysis (Byrne, 2013). To determine statistical significance, critical ratio (C.R.) was correlation coefficients between constructs and the square of AVE values. Discriminant validity is supported if the square of AVE value is greater than R2 between the variables. calculated by dividing the non-standardized coefficient by the standard error, and C.R. values of over 1.965 are considered to be statistically significant. Model fit analysis revealed $x^{2}=127.396(\mathrm{DF}=79), \mathrm{CMIN} / \mathrm{DF}=1.613, \mathrm{GFI}=$ $0.938, \mathrm{AGFI}=0.905, \mathrm{CFI}=0.968, \mathrm{TLI}=0.957, \mathrm{NFI}=0.921$ RMSEA $=0.049$, and $\mathrm{RMR}=0.063$, indicating good fit of the model.

Table 6. Results of Hypothesis Tests

\begin{tabular}{cccccc}
\hline Paths & Esti & S.E & T & P & Results \\
\hline IEM $\rightarrow$ ATT & 1.00 & .16 & 6.1 & $* * *$ & Supported \\
IEM $\rightarrow$ SN & 1.08 & .19 & 5.6 & $* * *$ & Supported \\
IEM $\rightarrow$ PEF & 0.50 & .12 & 3.9 & $* * *$ & Supported \\
$\mathrm{ATT} \rightarrow$ CPB & 0.22 & .10 & 2.1 & 0.0 & Supported \\
$\mathrm{SN} \rightarrow$ CPB & 0.53 & .09 & 5.5 & $* * *$ & Supported \\
$\mathrm{PEF} \rightarrow$ CPB & - & .11 & - & 0.8 & Rejected \\
\hline${ }^{*} \mathrm{p}<0.05,{ }^{* *} \mathrm{p}<0.01,{ }^{* * *} \mathrm{p}<0.001$ & & & & &
\end{tabular}

Path analysis results revealed that the value of the nonstandardized coefficient to be $1.002^{* * *}(\mathrm{~T}=6.124)$ for $\mathrm{H} 1$, which therefore represents a significant impact of organizational IEM on consumer attitude. The values of the non-standardized coefficient between IEM and subjective norms and perceived environmental friendliness were $1.089^{* * *}(\mathrm{~T}=5.638)$ and $0.503^{* * *}(\mathrm{~T}=3.979)$, respectively, showing a statistically significant relationship. Therefore, $\mathrm{H} 1$ and $\mathrm{H} 2$ are accepted. Similar significant results were found for H4 $\left(0.221^{*}, \mathrm{~T}=2.118\right)$ and $\mathrm{H} 5\left(0.530^{* * *}, \mathrm{~T}=5.591\right)$ which assume the causal relationship of two variables (consumer attitude and subjective norms, respectively) with purchasing behavior for sustainable PCP. Therefore, $\mathrm{H} 4$ and H5 are accepted. However, the causal relationship of the perceived environmental friendliness of products with purchasing behavior for sustainable PCP (H6) was not statistically significant given the non-standardized coefficient of $-0.017(\mathrm{~T}=-0.146)$. Therefore, H6 is rejected.

\section{DISCUSSION AND CONCLUSION 6.1 Discussion}

In addition to environmental pollution, the impact business activities have on the environment has been a longstanding social issue. This concern has ultimately helped consumers make pro-environmental decisions and purchase sustainable products. To adapt to changing consumer behavior and better performance in the market, firms need to come up with innovative strategies. Through the literature review, we discovered that corporate environmental efforts centered around marketing activities do not attract additional consumer attention. In the context of research, there is a tendency for researchers to explore consumer attitudes toward green products as a whole, despite the fact that products have different attributes. Due to this limitation of previous research, we chose to examine the impact of organizational IEM, as a leading variable, on consumers' green purchasing behavior.
As a result, organizational IEM was found to be positively related with consumer attitude, thereby supporting H1. This hypothesis was formulated based on Ajzen's (1991) theory that favorable appraisal leads to a positive attitude and, subsequently, the intention to engage in a behavior. Indeed, organizational IEM had a positive impact on consumer attitude, which contributed to consumer intention to purchase sustainable PCP as a result. Amid growing attention to the health and safety of daily use products, consumer preference for sustainable PCP is increasing (Marcoux, 2000). Therefore, it is crucial for firms to create a green corporate image by incorporating IEM practices into their marketing strategies for consumers.

Organizational IEM also showed a positive impact on subjective norms (H2). This result implies that organizational IEM exerts a positive effect in a social perspective. It also matches Suki's (2016) finding that environmental efforts and activities performed by employees help consumers develop positive subjective norms, thereby influencing their purchasing behavior. IEM practices, when disclosed to consumers continuously, can increase their positive subjective norms and promote their purchase intention.

Organizational IEM had a positive impact on consumers' perceived environmental friendliness of products (H3). Firms need to implement IEM strategies focused on consumer interest as a way to improve consumers' perception of the environmental friendliness of their products. Thus, environmental information, despite its intangible nature, can impact consumer perception of products.

Under $\mathrm{H} 4$ and $\mathrm{H} 5$, a positive relationship of consumer attitude and subjective norms with their purchasing behavior for sustainable PCP was confirmed. This result is consistent with the findings of earlier studies that consumer attitude and subjective norms translate into the intention to perform the behavior under consideration (Kim and Chung, 2011; Liobikienè and Bernatoniené, 2017; Paul et al., 2016). As $\mathrm{H} 4$ and $\mathrm{H} 5$ are accepted, we can suggest there is new value that results from the expansion of internally focused 
environmental activities to incorporate consumer participation.

Finally, the perceived environmental friendliness of products did not influence purchasing behavior for sustainable PCP (H6). This result is inconsistent with previous evidence showing that perceived sustainable products affect consumer purchasing behavior (Lee at al., 2012; Rahbar and Wahid, 2012). Kim and Seock (2009) and Liobikienè and Bernatonienè (2017) explained that consumers' purchasing process for sustainable PCP differs from that of other products. The rejection of H6 implies that the characteristics of sustainable PCP demand different marketing strategies of IEM than those used for general green products.

In addition, clear communication is necessary to help consumers perceive the environmental friendliness of products. D'Souza et al. (2006) said that there are many cases in which unclear labeling makes it difficult for consumers to identify green products. A standardized certification mark that could be used nationally would also improve the accuracy issues involved in the environmental friendliness of products. Consumers also need training programs designed to improve their environmental knowledge; environmental campaigns represent one such program. In addition, inconveniences encountered during the purchasing process (Moser, 2015), high price and low quality (Olson, 2013), and trivial environmental effects (Peattie, 2010) are known to undermine consumers' behavioral intention for perceived green products. This highlights the importance of strategies established from a consumer perspective, rather than a business perspective, to boost consumer perception of eco-friendly products.

\subsection{Implications}

This study examines the impact of organizational IEM on consumer purchase intention for sustainable PCP through its relationship with consumer attitude, subjective norms, and the perceived environmental friendliness of products. Study results suggest the need for integrated environmental strategies that combine internal and external environmental issues, such as consumers' increasing environmental awareness and consumption patterns. Strategies focused only on external environmental activities no longer draw consumer attention. Pro-environmental behaviors from top management, employees' environmental efforts, and quality environmental management have positive effects on consumer decision making. Therefore, a combination of external and internal environmental activities could be a good approach for organizations.

It was found that consumers' perception of green products alone does not result in purchasing behavior for sustainable PCP. The perceived environmental friendliness of products had no effect on purchasing behavior for sustainable PCP; this differs from the findings of earlier studies. The motivations behind purchases of sustainable PCP include physical health, harmless ingredients, and environmental protection (Kim and Chung, 2011). Given the motives underlying purchases of sustainable PCP, sales strategies for sustainable PCP must be differentiated from those for other consumer goods.
Finally, the present study expanded the environmental management framework beyond the internal perspective by using a consumer viewpoint. Consumer attention to IEM is expected to further grow in the future, thereby signaling the importance of including the consumer viewpoint in the corporate decision-making process. Sharing information on internal management practices and efforts with consumers will enable firms to build consumer trust in green products. Such an effort and environment strategies, type of product, sustainable supply chain will help companies maintain competitive advantage (Gyarmathy et al., 2020) by staying ahead in the sustainable PCP market.

Environmental pollution is an ongoing problem, and consumers are increasingly yearning for health and air pollution solutions, for which changes in consumer attitude and business practices seem inevitable. The present study proposes the following implications. First, sustainable PCP requires different sales strategies than those used for other consumer goods. As mentioned above, H6 is rejected because consumer behavior in sustainable PCP is different from that seen in general sustainable products. Therefore, a differentiated approach toward sustainable PCP is critical. Furthermore, the fact that the PCP market is growing in line with the organic food market deserves attention because growth barriers have emerged in the organic food market as consumer distrust toward green products grows (Nuttavuthisit and Thøgersen, 2017). As such, strategies for improving consumer trust are also required for sustainable PCP.

In addition, investment into IEM and the continuous disclosure of related information are also necessary. Organizational IEM, which was largely performed from an internal perspective, now includes the increasing involvement of consumers. As consumers tend to develop distrust and skepticism toward conventional promotional and advertising activities, proving corporate integrity is important for advertising strategies. Employing top managers capable of driving environmental activities, increasing employee efforts to protect the environment, and continuously investing in environmental training and rewarding environmental activities are also recommended. By sharing information on IEM, firms can promote their environmental image in a trustful manner.

\subsection{Limitations and Future Research}

In the present study, the framework for an organization's internal environmental activities was measured from a consumer perspective. As the study involved ordinary consumers, their knowledge and understanding of IEM practices may be lacking. Such a possible limitation makes it uncertain whether the present findings can be applied to real business settings. However, the respondents had an opportunity to access the knowledge and information they needed to evaluate corporations' internal environmental activities. The information they obtained eventually influenced their decision making. In future studies, the consumers' perspective of internal corporate activities can be considered more specifically and easily to create a better research framework. The present study focused on sustainable PCP as a defined category of sustainable products that are widely available across many 
industries. However, consumers' purposes and motives for using sustainable PCP vary depending on gender, age, and location, in addition to the different features of products. Therefore, further category segmentation in sustainable PCP will improve the accuracy of research findings.

\section{REFERENCES}

U.S.Food and Drug Administration. [online] https://www.fda.gov/cosmetics/resources-consumerscosmetics/cosmetics-safety-qa-personal-careproducts/ (Accessed 22 May 2020).

Nielson. [online] https://www.nielsen.com/us/en/insights/article/2017/w hen-it-comes-to-personal-care-ingredients- matter/ (Accessed 16 Aug 2020).

Personal Care Products Council [online] https://www.personalcarecouncil.org/sciencesafety/sustainability/ (Accessed 20 April 2020).

Cosmetics Design Asia ${ }^{a}$ [online] https:/www.cosmeticsdesignasia.com/Article/2020/03/24/Going-green-is-thefuture-of-China-s- cosmetics-industry-Clariant/ (Accessed 3 April 2020).

Cosmetics Design Asia ${ }^{\mathrm{b}}$ [online] https://www.cosmeticsdesignasia.com/Article/2020/07/16/Meeting-consumerexpectations-remain- key-challenge-in-sustainabilityefforts (Accessed 15 August 2020).

Korea Cosmetics Association [online] https://kcia.or.kr/home/industry/industry_01.php?type $=$ view $\&$ no $=12481 \&$ ss $=$ page $\% 3 \mathrm{D} \% 26$ skind $\% 3 \mathrm{DTITL}$ E_CNTNT\%26sword\%3D2019+\%ED $\% 99 \% 94 \%$ EC \%9E\%A5\%ED\%92\%88\%26ob\%3D (Accessed 15 August 2020).

Ajzen, I. (1991). The theory of planned behaviour. Organizational Behavior and Human Decision Processes, 50(2), pp. 179-211.

Ajzen, I., \& Sheikh, S. (2013). Action versus inaction: Anticipated affect in the theory of planned behaviour. Journal of Applied Social Psychology, 43(1), pp. 155162.

Albayrak, T., Aksoy, Ş., \& Caber, M. (2013). The effect of environmental concern and scepticism on green purchase behaviour. Marketing Intelligence \& Planning, 30(1), pp. 27-39.

Albino, V., Balice, A., \& Dangelico, R. M. (2009). Environmental strategies and green product development: An overview on sustainability driven companies. Business Strategy and the Environment, 18(2), pp.83-96.

Arbuckle, J.L. (2006), Amos 7.0 User's Guide,. SPSS, Chicago.

Arvola, A., Vassallo, M., Dean, M., Lampila, P., Saba, A., Lähteenmäki, L., \& Shepherd, R. (2008). Predicting intentions to purchase organic food: The role of affective and moral attitudes in the theory of planned behaviour. Appetite, 50(2-3), pp. 443-454.

Bals, L., \& Tate, W. L. (2018). Sustainable supply chain design in social businesses: advancing the theory of supply chain. Journal of Business Logistics, 39(1), pp. 57-79.

Boyce, W. S., \& Mano, H. (2018). An inquiry into the supplier selection decision from the business-toconsumer (B2C) perspective. Journal of Business \& Industrial Marketing, 33(8), pp. 1221-1230.

Byrne, B. M. (2013), Structural equation modeling with Mplus: Basic concepts, applications, and programming, routledge, New York.

Carrington, M. J., Neville, B. A., \& Whitwell, G. J. (2014). Lost in translation: Exploring the ethical consumer intention-behavior gap. Journal of Business Research, 67(1), pp. 2759-2767.

Chen, T. B., \& Chai, L. T. (2010). Attitude towards the environment and green products: Consumers' perspective. Management Science and Engineering, 4(2), pp. 27-39.

Cho, M., Bonn, M. A., \& Kang, S. (2015). The moderating effects of retailers' green practices upon customer environmental values and organic food purchasing intention. Journal of Distribution Science, 13(11), pp. $5-13$.

Connell, K. Y. H. (2010). Internal and external barriers to eco-conscious apparel acquisition. International Journal of Consumer Studies, 34(3), pp. 279-286.

Dou, Y., Zhu, Q., \& Sarkis, J. (2018). Green multi-tier supply chain management: An enabler investigation. Journal of Purchasing and Supply Management, 24(2), pp. 95-107.

De Cannière, M. H., De Pelsmacker, P., \& Geuens, M. (2009). Relationship quality and the theory of planned behavior models of behavioral intentions and purchase behavior. Journal of Business Research, 62(1), pp. 8292.

De Leeuw, A., Valois, P., Ajzen, I., \& Schmidt, P. (2015). Using the theory of planned behavior to identify key beliefs underlying pro-environmental behavior in highschool students: Implications for educational interventions. Journal of Environmental Psychology, 42, pp. $128-138$

D'Souza, C., Taghian, M., Lamb, P., \& Peretiatkos, R. (2006). Green products and corporate strategy: An empirical investigation. Society and Business Review, 1(2), pp. 144-157.

Essoussi, L. H., \& Zahaf, M. (2008). Decision making process of community organic food consumers: An exploratory study. Journal of Consumer Marketing, 25(2), pp. 95-104.

Fawcett, S. E., \& Waller, M. A. (2014). Supply chain game changers mega, nano, and virtual trends and forces that impede supply chain design (ie, building a winning team). Journal of Business Logistics, 35(3), pp. 157164.

Ghazali, E., Soon, P. C., Mutum, D. S., \& Nguyen, B. (2017). Health and cosmetics: Investigating consumers' values for buying organic personal care products. Journal of Retailing and Consumer Services, 39, pp.154-163.

Gyarmathy, A., Peszynski, K., \& Young, L. (2020). Theoretical Framework for a Local, Agile Supply Chain to Create Innovative Product Closer to End-user: 
Onshore-Offshore Debate. Operations and Supply Chain Management: An International Journal, 13(2), pp. 108-122.

Hair, J. F., Black, W. C., Babin, B. J., \& Anderson R. E. (2010), Multivariate date analysis, Prentice Hall, New Jersey.

Han, H., \&Kim, Y. (2010). An investigation of green hotel customers' decision formation: Developing an extended model of the theory of planned behaviour. International Journal of Hospitality Management, 29(4), pp. 659-668.

Hoejmose, S., Brammer, S., \& Millington, A. (2012). Green supply chain management: The role of trust and top management in B2B and B2C markets. Industrial Marketing Management, 41(4), pp. 609-620.

Hsu, C. L., Chang, C. Y., \& Yansritakul, C. (2017). Exploring purchase intention of green skincare products using the theory of planned behavior: Testing the moderating effects of country of origin and price sensitivity. Journal of Retailing and Consumer Services, 34, pp. 145-152.

Jonas, A., \& Roosen, J. (2005). Private labels for premium products-the example of organic food. International Journal of Retail \& Distribution Management, 33(8), pp. 636-653.

Joshi, Y., \& Rahman, Z. (2015). Factors affecting green purchase behaviour and future research directions. International Strategic Management Review, 3(1-2), pp. 128-143.

Kim, H. Y., \& Chung, J. E. (2011). Consumer purchase intention for organic personal care products. Journal of consumer Marketing, 28(1), pp. 40-47.

Kim, S., \& Seock, Y. K. (2009). Impacts of health and environmental consciousness on young female consumers' attitude towards and purchase of natural beauty products. International Journal of Consumer Studies, 33(6), pp. 627-638.

Kong, W., Harun, A., Sulong, R. S., \& Lily, J. (2014). The influence of consumers' perception of green products on green purchase intention. International Journal of Asian Social Science, 4(8), pp. 924-939.

Lee, N., Choi, Y. J., Youn, C., \& Lee, Y. (2012). Does green fashion retailing make consumers more eco-friendly? The influence of green fashion products and campaigns on green consciousness and behaviour. Clothing and Textiles Research Journal, 30(1), pp. 67-82.

Liobikienè, G., \& Bernatonienè, J. (2017). Why determinants of green purchase cannot be treated equally? The case of green cosmetics: Literature review. Journal of Cleaner Production, 162, pp. 109120.

Liobikienè, G., Mandravickaitè, J., \& Bernatonienè, J. (2016). Theory of planned behavior approach to understand the green purchasing behavior in the EU: A cross-cultural study. Ecological Economics, 125, pp. $38-46$.

Marcoux, D. (2000). Appearance, cosmetics, and body art in adolescents. Dermatologic Clinics, 18(4), pp. 667-673.

Moser, A. K. (2015). Thinking green, buying green? Drivers of pro-environmental purchasing behaviour. Journal of Consumer Marketing, 32(3), pp. 167-175.
Mukhtar, U., \& Azhar, T. (2020). Inter-functional Coordination to Co-create Value Within Integrated Value Chains for Competitive Supply Chain. Operations and Supply Chain Management: An International Journal, 13(1), pp. 11-22.

Nijkamp, M. M., Bokkers, B. G. H., Bakker, M. I., Ezendam, J., \& Delmaar, J. E. (2015). Quantitative risk assessment of the aggregate dermal exposure to the sensitizing fragrance geraniol in personal care products and household cleaning agents. Regulatory Toxicology and Pharmacology, 73(1), pp. 9-18.

Nuttavuthisit, K., \& Thøgersen, J. (2017). The importance of consumer trust for the emergence of a market for green products: The case of organic food. Journal of Business Ethics, 140(2), pp. 323-337.

Olson, E. L. (2013). It's not easy being green: The effects of attribute tradeoffs on green product preference and choice. Journal of the Academy of Marketing Science, 41(2), pp. 171-184.

Pattnaik, S., \& Pattnaik, S. (2019). Relationships between Green Supply Chain Drivers, Triple Bottom Line Sustainability and Operational Performance: An Empirical Investigation in the UK Manufacturing Supply Chain. Operations and Supply Chain Management: An International Journal, 12(4), pp. 198-211.

Paul, J., Modi, A., \& Patel, J. (2016). Predicting green product consumption using theory of planned behavior and reasoned action. Journal of Retailing and Consumer Services, 29, pp. 123-134.

Peattie, K. (2010). Green consumption: Behavior and norms. Annual Review of Environment and Resources, 35(3), pp.195-228.

Pudaruth, S., Juwaheer, T. D., \& Seewoo, Y. D. (2015). Gender-based differences in understanding the purchasing patterns of eco-friendly cosmetics and beauty care products in Mauritius: A study of female customers. Social Responsibility Journal, 11(1), pp. 179-198.

Pujari, D., Wright, G., \& Peattie, K. (2003). Green and competitive: Influences on environmental new product development performance. Journal of Business Research, 56, pp. 657-671.

Rahbar, E., \& Wahid, N. A. (2011). Investigation of green marketing tools' effect on consumers' purchase behaviour. Business Strategy Series, 12(2), pp. 73-83.

Ritter, Á. M., Borchardt, M., Vaccaro, G. L., Pereira, G. M., \& Almeida, F. (2015). Motivations for promoting the consumption of green products in an emerging country: Exploring attitudes of Brazilian consumers. Journal of Cleaner Production, 106, pp. 507-520.

Suki, N. M. (2016). Consumer environmental concern and green product purchase in Malaysia: Structural effects of consumption values. Journal of Cleaner Production, 132, pp. 204-214.

Ta, H., Esper, T., \& Hofer, A. R. (2015). Business-toconsumer (B2C) collaboration: Rethinking the role of consumers in supply chain management. Journal of Business Logistics, 36(1), pp. 133-134.

Todd, A.M. (2004). The aesthetic turn in green marketing: Environmental consumer ethics of natural personal 
care products. Ethics and the Environment, 9(2), pp. 86-102.

Tseng, S. C., \& Hung, S. W. (2013). A framework identifying the gaps between customers' expectations and their perceptions in green products. Journal of Cleaner Production, 59, pp. 174-184.

Tundys, B., \& Tomasz Wisniewski, T. (2020). Green Supply Chain Management Evaluation for Organic Products: Theoretical and Empirical Point of View. Operations and Supply Chain Management: An International Journal, 14(1), pp. 73-82.

Yadav, R., \& Pathak, G. S. (2017). Determinants of consumers' green purchase behavior in a developing nation: Applying and extending the theory of planned behaviour. Ecological Economics, 134, pp. 114-122.

Zhu, Q., \& Sarkis, J. (2004). Relationships between operational practices and performance among early adopters of green supply chain management practices in Chinese manufacturing enterprises. Journal of Operations Management, 22(3), pp. 265-289.

Zhu, Q., Sarkis, J., Cordeiro, J. J., \& Lai, K. H. (2008). Firmlevel correlates of emergent green supply chain management practices in the Chinese context. Omega, 36(4), pp. 577-591.

Byoung-Chun Ha is a professor of business administration at Sogang University and teaches Operations Management, Logistics, and Supply Chain Management. He holds a bachelor's degree in business from Sogang University. After completing his MBA at George Washington University, he received his Ph.D. from the same graduate school.

So-Youn Lim holds a master's degree in cosmetology from Chung-Ang University. After that, she received her Ph.D. in Global Service Management at Sogang University. Her areas of interest are in Green Supply Chain Management and Eco-friendly marketing strategy.

Changjoon Lee holds a bachelor's degree in economics from Michigan State University, and a master's degree from Sogang University, majoring in LSOM (Logistics, Services, Operations Management). Currently, he is working on a doctorate in LSOM, at Sogang University. His areas of interest are in Operations Management, Supply Chain Management, and Health Care Management. 